\section{СПИСОК ВИКОРИСТАНОЇ ЛІТЕРАТУРИ}

Удовиченко, I. В. (2018). Концептуальні засади змісту навчання географії учнів старшої школи на профільному рівні: монографія. Київ: Педагогічна думка. 360 с.

Овчарук, О. В. (2004). Концептуальні підходи у сучасній освіті: світовий досвід та українські перспективи. Київ: K.I.C. 112 с.

Топузов, О. М., Надтока, А. Ф., Покась, Л. А. (2008). Географія. Україна у світі: природа, населення: підручник для 8 класу загальноосвітніх навчальних закладів. Київ: Генеза. 288 с.

Державний стандарт базової та повної середньої освіти (2012). Урядовий кур'єр. 195 с.

Рекуненко, В. В. (1995). Методика проведення бінарних занять. Київ: НМК з підготовки молодших спеціалістів. 277 с.
Карпюк, О. Д. (2008). Англійська мова: підручник для 8 класу загальноосвітніх навчальних закладів. Тернопіль: Астон. 260 с.

Паламарчук, Л. Б. (2004). Територія України: історико-географічний аспект. Бібліотека журналу «Географія». Харків: Видавнича група «Основа». 143 с.

Костенко, Л. В. (2006). Географія України: довідник. Харків: Веста. 152 с.

Бібік, Н. М. (2004). Компетентнісний підхід: рефлексивний аналіз застосування. Компетентніснии підхід у сучасній освіті: світовий досвід та украӥнські перспективи. Київ: К.І.С. С. 47-53.

Дата надходження до редакиії: 07.04.2021 p.
УДК 378.147:[338.488.2:640.4]

DOI: 10.37026/2520-6427-2021-106-2-32-38
Валентина БУРАК,

кандидат технічних наук, дочент, доиент кафедри готельно-ресторанного та туристичного бізнесу

Херсонського державного університету, м. Херсон, Украӥна ORCID: 0000-0001-9085-9000

e-mail:burak_valia@ukr.net

\title{
СПЕЦИФІКА ФОРМУВАННЯ КОМПЕТЕНТНОСТІ МАЙБУТНІХ ФАХІВЦІВ ГОТЕЛЬНО-РЕСТОРАННОӤ СПРАВИ У ПРОЦЕСІ ПРОФЕСІЙНОӤ ПІДГОТОВКИ В ЗАКЛАДАХ ВИЩОЇ ОСВІТИ
}

\begin{abstract}
Анотація. У статті представлено структур но-системний аналіз процесу формування компетентності майбутніх фахівиів готельно-ресторанноі справи у проиесі професійної підготовки в закладах вищої освіти. На основі опрацювання досліджень науковців із проблеми підготовки майбутніх фахівців сфери обслуговування в закладах вищої освіти здійснено диференціацію низки компетентностей означених фахівиів. Дефініцію «компетентність майбутніх фахівиів готельно-ресторанної справи» визначено як полікомпонентну динамічну комбінацію, представлену знаннями, вміннями, навичками, способами мислення, поглядами, иінностями, іншими особистими якостями, зреалізовану наскрізно на рівнях вищоі освіти галузі знань 24 «Сфера обслуговування», спеиіальності 241 «Готельно-ресторанна справа», формах організації навчання, шо є комплексом інтегральної, загальних («м'які» навички) $і$ спечіальних («тверді» фахові, предметні навички) компетентностей та визначає здатність здобувача освіти успішно соиіалізуватися, провадити професійну та/або подальшу навчальну діяльність, самостійно й цілеспрямовано
\end{abstract}

підвищувати фахову компетентність, розбудовувати кар 'єру та формувати власну кониепцію життєвого успіху. До загальних компетентностей нами віднесено такі: культурологічну, полікультурну, морально-етичну, сочіальну, здоров'язбережувальну, громадянську, релігієзнавчу, світоглядну, ичивілізачійну, космополітичну, художньо-естетичну, мовно-комунікативну, полілінгвальну, риторичну, гуманітарну, психолого-фасилітативну, емоиійно-інтелектуальну, самоосвітню, критичного мислення, креативну, інформаційно-цифрову, медіакомпетентність, інклюзивнау, рефлексивну. Відповідно до спеціальних компетентностей - конкретно-професійну, правову, науково-дослідницьку, експериментальну, екологічну, соиіально-економічну, підприємнииьку, інноваційну, інструментально-аналітичну, дискурсивну, технічну, технологічну, лідерсько-управлінську, моніторингово-діагностичну, експертну, прогностично-моделюючу, сталості.

Ключові слова: готельно-ресторанна справа, професійна підготовка, майбутній фахівець, компетентність. 
Valentyna BURAK,

Candidate of Technical Sciences

Department of hotel-restaurant and tourist business

Kherson State University,

Kherson, Ukraine

ORCID: 0000-0001-9085-9000

e-mail:burak_valia@ukr.net

\section{SPECIFICS OF COMPETENCE FORMATION OF FUTURE SPECIALISTS IN HOTEL AND RESTAURANT BUSINESS IN THE PROCESS OF PROFESSIONAL TRAINING IN HIGHER EDUCATIONAL ESTABLISHMENTS}

\begin{abstract}
The article provides a structural and systematic analysis of the process of competence forming of future specialists in hotel and restaurant business during training in higher educational establishments. Based on different scientific researches on the problems of training future specialists in the service sector in higher educational establishments a complex of future specialists' competences was differentiated. The definition of the concept of "competence of future specialists in hotel and restaurant sector» is defined as a multicomponent dynamic combination, represented by knowledge, skills, abilities, ways of thinking, views, values, other personal qualities, implemented through higher education in the field of knowledge 24 «Service» 241 «Hotel and restaurant business», forms of education, which is a complex of integrated, general (soft skills) and special (hard professional, subject skills) competencies and determines student's ability to successfully socialize, conduct professional and / or further educational activities, independently and purposefully individually increase professional competence, build a career and form your own concept of life success. We include cultural, multicultural, moral and ethical, social, health, civil, religious, ideological, civilizational, cosmopolitan, artistic and aesthetic, linguistic and communicative, polylingual, rhetorical, humanitarian and psychological, self-educational, critical thinking, creative, information-digital, media competence, inclusive, reflective. Special competencies are: specific-professional, legal, research, experimental, ecological, socio-economic, entrepreneurial, innovative, instrumental-analytical, discursive, technical, technological, leadership-managerial, monitoring-diagnostic, expert, prognostic-prognostic, sustainability. Scientific research, analysis and research have made it possible to determine a set of competencies for successful socialization, professional activities, career development and formation of own concept of life success.
\end{abstract}

Key words: hotel and restaurant industry, professional training, future specialists, competence.

Постановка проблеми. Основною проблемою вітчизняної вищої освіти визначено неспроможність випускників закладів вищої освіти (далi - 3BO) повною мірою реалізувати себе на внутрішньому ринку праці. Означена проблема стосується не лише здобувачів вищої освіти, а й впливає на суспільство загалом, унеможливлюючи його гармонійний розвиток без конкурентоспроможних фахівців.

На сьогодні справжніми викликами для вітчизняної освіти є їі якість, проблеми соціально-економічного характеру, відтік людського капіталу, низький рівень фінансування у зв'язку з бюджетними обмеженнями та ін. Зокрема якість вищої освіти не відповідає очікуванням усіх зацікавлених осіб (стейкхолдерів) освітнього процесу - держави, закладів вищої освіти, здобувачів освіти, бізнесу, роботодавців, суспільства загалом. За цих обставин здобувачі вищої освіти нерідко не мають необхідних для здійснення навчально-пізнавальної діяльності знань, розвинених навичок, сформованих компетентностей та мотивації як для навчання, так і для майбутньої професійної діяльності. Крім того, варто зауважити, що нині в Україні відсутні дані щодо динаміки оцінки роботодавцями і замовниками освітніх послуг якості вищої освіти та відповідності пропонованих ЗВО освітніх програм вимогам сучасного швидкозмінюваного ринку праці, а також моніторинг щодо працевлаштування випускників та перспектив їхнього кар'єрного зростання впродовж життя.

Аналіз наукових досліджень і публікацій. Аналіз науково-педагогічної літератури, а також напрацювань із галузі знань «Сфера обслуговування» засвідчує певну розробленість питання професійної підготовки майбутніх фахівців готельно-ресторанної галузі та уможливлює визначення таких напрямів досліджень:

- підготовка майбутніх фахівців сфери обслуговування в закладах вищої освіти (Іванова, 2018; Шевчук, 2018);

- формування ключових компетентностей майбутніх фахівців сфери обслуговування (Радкевич, Кравець, Козак, 2020; Шестель, Куракін, Бишовець, 2020);

- особливості підготовки фахівців туризму й готельної справи (Зінченко, 2017; Камишнікова, 2017; Мединська, 2020);

- особливості підготовки майбутніх фахівців із туризмознавства (Безкоровайна, 2018);

- структура та компоненти професійної готовності фахівців із туризму (Земліна, 2013);

- професійна підготовка майбутніх фахівців готельно-ресторанної справи (Бурак, 2020; Гончар, 2020; Дмитренко, Каролоп, 2020; Полуда, 2010; Приймук, 2016). 
Метою статті $є$ здійснення структурно-системного аналізу процесу формування компетентності майбутніх фахівців готельно-ресторанної справи у процесі професійної підготовки в закладах вищої освіти; визначення специфіки формування й оновлення комплексу компетентностей в умовах глобалізаційних змін і реформування галузі освіти в Україні.

Виклад основного матеріалу дослідження. У контексті нашого дослідження передусім варто розглянути дефініцію «професійна підготовка майбутніх фахівців готельно-ресторанного господарства", під якою ми розумітимемо «організований, безперервний, иілеспрямований процес формування і розвитку в здобувачів освіти необхідних для фахової діяльності професійних компетентностей, який здійснюється в закладах вищої освіти різних форм власності, спрямований на здобуття майбутніми фахівиями кваліфікаиій відповідно до освітньо-професійних програм освітніх рівнів «бакалавр» $i$ «магістр» спеиіальності 241
«Готельно-ресторанна справа», щуо слугуватиме забезпеченню успішного виконання посадових обов 'язків, конкурентоспроможності та професійній мобільності у сфері послуг».

Відповідно до Концепції «Нова українська школа» (2016) поняття «компетентність» трактують як «динамічну комбінацію знань, умінь, навичок, способів мислення, поглядів, цінностей, інших особистих якостей, щзо визначає здатність особи успішно соиіалізуватися, провадити професійну та/або подальшу навчальну діяльність».

Багатоаспектні дослідження науковців щодо проблем підготовки в закладах вищої освіти майбутніх фахівців сфери обслуговування, зокрема й готельно-ресторанної справи, у ЗВО уможливили проведення аналізу з метою визначення дослідниками комплексу компетентностей майбутніх фахівців сфери обслуговування до професійної діяльності, які подано нами у таблиці 1.

Таблиия 1

Диференціація комплексу компетентностей майбутніх фахівців сфери обслуговування

\begin{tabular}{|c|c|}
\hline $\begin{array}{c}\text { Автори- } \\
\text { досллідники }\end{array}$ & Види компонентів \\
\hline $\begin{array}{l}\text { Л. Безкоровайна } \\
\text { (2018) }\end{array}$ & $\begin{array}{l}\text { Компетентності фахівиів із туризмознавства: } \\
\text { - } \quad \text { системні - здатність до застосування отриманих знань у практичній діяльності, неперервного } \\
\text { навчання впродовж життя; удосконалення знань та вмінь упродовж усієї професійної діяльності, } \\
\text { постійний саморозвиток, підвищення кваліфікації і майстерності; досягнення мети і критичного } \\
\text { переосмислення накопиченого досвіду; опанування світоглядною, економічною, екологічною } \\
\text { культурою; } \\
\text { - інструментальні - готовність до реалізації проєктів у туристичній галузі, розробки продукту } \\
\text { завдяки сучасним інформаційно-комунікаційним технологіям; здатність знаходити, аналізувати і } \\
\text { обробляти інформацію в галузі туристичної діяльності з використанням інформаційно-комунікаційних } \\
\text { технологій, здійснювати оперативний пошук інформації щодо можливих пропозицій туристичного } \\
\text { ринку, аналізувати та підбирати програми обслуговування; } \\
\text { - міжсособистісні - здатність працювати в команді, керувати людьми, дотримуватися субординації; } \\
\text { уміння оцінювати власні достоїнства й недоліки, обирати шляхи та засоби щодо іх розвитку чи } \\
\text { усунення; здатність до безконфліктної професійної діяльності; уміння створювати позитивну } \\
\text { атмосферу в колективі; здатність і готовність працювати в міжнародному туристичному середовищі }\end{array}$ \\
\hline $\begin{array}{l}\text { Л. Гончар } \\
(2020)\end{array}$ & 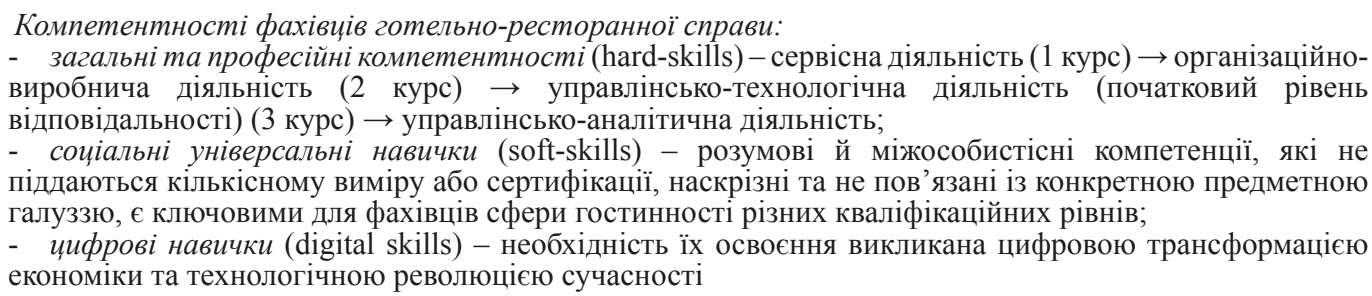 \\
\hline $\begin{array}{l}\text { Г. Дмитренко, } \\
\text { О. Каролоп } \\
(2020)\end{array}$ & $\begin{array}{l}\text { Компетентності фахівців із готельно-ресторанної справи: } \\
\text { - базові компетенції-мотиваційна, когнітивно-творча, комунікативна; } \\
\text { - фахові компетентності - здатність організовувати сервісно-виробничий процес з урахуванням } \\
\text { вимог і потреб споживачів; використовувати на практиці основи діючого законодавства у сфері } \\
\text { готельно-ресторанного бізнесу, відстежувати зміни, формувати й реалізовувати ефективні зовнішні } \\
\text { та внутрішні комунікації, навички взаємодії; управляти підприємством, приймати рішення в } \\
\text { господарській діяльності, проєктувати технологічний процес виробництва продукції і послуг, а також } \\
\text { сервісний процес реалізації основних і додаткових послуг; розробляти нові послуги (продукцію) } 3 \\
\text { використанням інноваційних технологій виробництва та обслуговування споживачів з урахуванням } \\
\text { сучасного стану і перспектив розвитку готельно-ресторанної індустрії; розробляти, просувати, } \\
\text { реалізовувати та організовувати споживання послуг для різних сегментів споживачів }\end{array}$ \\
\hline $\begin{array}{l}\text { Ю. Земліна } \\
\text { (2013) }\end{array}$ & $\begin{array}{l}\text { Компетентності фахівців із туризму: } \\
\text { - фахові компетентності бакалавра - технологічна, дослідно-аналітична, сервісна, організаційна, } \\
\text { управлінська); } \\
\text { - фахові компетентності магістра - дослідно-аналітична, } \\
\text { організаційно-управлінська, проєктно-інноваційна }\end{array}$ \\
\hline
\end{tabular}


Продовження таблийі 1

\begin{tabular}{|c|c|}
\hline $\begin{array}{c}\text { Автори- } \\
\text { дослідники }\end{array}$ & Види компонентів \\
\hline $\begin{array}{l}\text { В. Зінченко } \\
\text { (2017) }\end{array}$ & $\begin{array}{l}\text { Компетентності фахівиів із туризму та готельно-ресторанної справи: } \\
\text { - особистісна компетентність - аксіологічна, персональна, інформаційна, екологічна, валеологічна; } \\
\text { - } \text { професійна компетентність-соціальна, комунікативна, організаційна, пошуково-реконструктивна, } \\
\text { анімаційна, аутокомпетентність }\end{array}$ \\
\hline $\begin{array}{l}\text { О. Іванова } \\
\text { (2018) }\end{array}$ & $\begin{array}{l}\text { Компетентності фахівиів сфери послуг: } \\
\text { - професійні компетенції - компетенція самовдосконалення, компетенція економіко-правової } \\
\text { культури, інформаційна компетенція, іншомовна, навчально-пізнавальна, соціокультурна, управлінська, } \\
\text { громадянська, комунікативна, соціально-трудова, ціннісно-смислова }\end{array}$ \\
\hline $\begin{array}{l}\text { В. Полуда } \\
\text { (2010) }\end{array}$ & $\begin{array}{l}\text { Компетентності фахівиів із готельного господарства: } \\
\text { - засадничі спеціальні професійні компетенції - знання основних державних документів у сфері } \\
\text { туризму та готельних підприємств, правила користування та внутрішнього розпорядку в готелі; } \\
\text { правила техніки безпеки, електробезпеки, протипожежної безпеки і виробничої санітарії та гігієна; } \\
\text { нормативно-правові документи, що забезпечують приймання та обслуговування; технології прийому } \\
\text { та обслуговування гостей, стандартів обслуговування; знання однієї-двох іноземних мов у межах } \\
\text { професійно-орієнтованої лексики; } \\
\text { - ключові спеціальні компетениї - здатність забезпечувати необхідний рівень якості готельних } \\
\text { послуг, організовувати роботу підрозділу } 3 \text { дотримання правил техніки безпеки, електробезпеки, } \\
\text { протипожежної безпеки івиробничої санітарії та гігієни, упередження конфліктних ситуацій відповідно } \\
\text { до норм гостинності за правилами міжнародного етикету і стандартів обслуговування, коригування } \\
\text { номенклатури та обсягів надання послуг, володіння сучасними інформаційними технологіями }\end{array}$ \\
\hline $\begin{array}{l}\text { С. Шевчук } \\
\text { (2018) }\end{array}$ & $\begin{array}{l}\text { Компетентності фахівців сфери обслуговування: } \\
\text { - ключові компетенції - базові (мотиваційна, когнітивно-творча, комунікативна), соціальна, } \\
\text { психологічна, інформаційна, комунікативна, валеологічна, екологічна }\end{array}$ \\
\hline
\end{tabular}

Зважаючи на представлений вище аналіз, термін «компетентність майбутніх фахівців готельно-ресторанної справи» трактуватимемо як полікомпонентну динамічну комбінацію, представлену знаннями, вміннями, навичками, способами мислення, поглядами, иінностями, іншими особистими якостями, зреалізовану наскрізно на рівнях вищої освіти галузі знань 24 «Сфера обслуговування», спеціальності 241 «Готельно-ресторанна справа», формах організації навчання, щзо $\epsilon$ комплексом інтегральної, загальних («м'які» навички) i спецінальних («тверді» фахові, предметні навички) компетентностей та визначає здатність здобувача освіти успішно соиіалізуватися, провадити професійну та/або подальшу навчальну діяльність, самостійно й иілеспрямовано індивідуально підвищувати фахову компетентність, розбудовувати кар 'єру та формувати власну концепцію життєвого успіху.

Залежно від змісту виокремлених нами компетентностей, конкретизуємо їх зміст та визначимо основні функціональні групи (див. табл. 2).

Таблиия 2

Функціональні групи компетентностей майбутніх фахівців готельно-ресторанної справи

\begin{tabular}{|c|c|}
\hline \multicolumn{2}{|c|}{ Функціональні групи компетентностей } \\
\hline \multicolumn{2}{|c|}{$\begin{array}{l}\text { Інтегральна компетентність - формування здатності вирішення складних спеціалізованих завдань та практичних } \\
\text { проблем у діяльності суб’єктів готельно-ресторанного бізнесу із застосуванням теорій і методів системи наук із метою } \\
\text { формування концепції гостинності, що характеризуються комплексністю та невизначеністю умов }\end{array}$} \\
\hline $\begin{array}{c}\text { Загальні компетентності } \\
\text { («м'які» навички - soft skills) }\end{array}$ & $\begin{array}{c}\text { Спеціальні (професійні) компетентності } \\
\text { («тверді» навички - hard skills) }\end{array}$ \\
\hline $\begin{array}{l}\text { Культурологічна-збереження та примноження моральних, куль- } \\
\text { турних, наукових цінностей і досягнень суспільства через усвідом- } \\
\text { лення уроків історії та закономірностей розвитку наукової галузі. } \\
\text { Морально-етична - норми, правила, вимоги, приписи, } \\
\text { принципи суспільств і стереотипи поведінки особистості, ії } \\
\text { моральні якості. } \\
\text { Полікультурна - поцінування та повага до різноманітності } \\
\text { й мультикультурності. } \\
\text { Соціальна - соціальна відповідальність та усвідомленість } \\
\text { ролі в загальній системі знань та розвиткові соціуму, техніки і } \\
\text { технологій; лідерство та соціальний вплив. } \\
\text { Здоров'язбережувальна - провадження безпечної діяльно- } \\
\text { сті, здоровий спосіб життя. } \\
\text { Громадянська - здатність бути громадянином із базовим рівнем } \\
\text { демократичної, громадянської культури, усвідомлення цінності сво- } \\
\text { боди, прав людини, відповідальності, готовність орієнтуватися у } \\
\text { проблемах сучасного суспільно-політичного життя в Україні. }\end{array}$ & $\begin{array}{l}\text { Конкретно-професійна - знання про предметну наукову } \\
\text { галузь і специфіку фахової діяльності; організацію сервісно- } \\
\text { виробничого процесу, вміння враховувати вимоги й потреби } \\
\text { замовників послуг та забезпечення ї ефективності. } \\
\text { Правова - реалізація своїх прав і обов’язків як члена } \\
\text { суспільства, верховенство права, прав і свобод людини і } \\
\text { громадянина, практичноговикористаннячинногозаконодавства } \\
\text { у сфері готельного та ресторанного бізнесу,врахування змін до } \\
\text { нього. } \\
\text { Інтерактивна - формування та реалізація ефективних } \\
\text { зовнішніх і внутрішніх комунікацій в установах сфери } \\
\text { гостинності, взаємодія та інтеракція. } \\
\text { Науково-дослідницька - розроблення, просування, } \\
\text { реалізація та організація процесу щодо споживання готельно- } \\
\text { ресторанних полуг з урахуванням різниці у сегменті } \\
\text { замовників. }\end{array}$ \\
\hline
\end{tabular}


Продовження таблийі 2

\section{Функціональні групи компетентностей}

Загальні компетентності
(«м'які» навички - soft skills)

Загальні компетентності
(«м'які» навички - soft skills)

Pеліхієзнавча - урахування світоглядних поглядів замовників послуг у міжособистісній та фаховій комунікації; розрізнення основних релігійних течій і напрямів; застосування основних норм релігійного етикету.

Світоглядна - розуміння ролі людини, сенсу іiі життя, переконань, принципів, цінностей; можливість формувати суспільний ідеал, власні науково-світоглядні позиції.

Цивілізаційна - розуміння майбутнього напряму розвитку людства в цілому та окремо взятої особистості зокрема, стресостійкість і гнучкість.

Космополітична - відчуття причетності до розумінням та вирішення планетарних проблем, дотриманням загальнолюдських цінностей світового громадянства.

Художньо-естетична - естетичні знання, сформовані вміння, навички, естетичні якості, здібності, здатності, цінності, ідеали, поводження, певний творчий досвід.

Логічна - оволодінням сучасними знаннями, вміннями, навичками, абстрактним мисленням, аналізом та синтезом, аргументованістю.

Мовно-комунікативна - спілкування державною мовою (усно та письмово).

Полілінгвальна - спілкування двома і більше іноземними мовами.

Риторична - використання засобів красномовства для впливу на адресата мовлення 3 метою переконання, вироблення спільних рішень.

Гуманімарна - вирішення стандартних і нестандартних ситуацій, формування культурних норм життєдіяльності; проведення моральної й культурної експертизи власної діяльності.

Психолого-фасилітативна - знання психофізіологічних особливостей людини, іiі потреб і способів задоволення відповідно до прийнятих культурних і соціальних норма, традицій.

Емоційно-інтелектуальна - розуміння себе, саморегуляція та мотивація, емпатія, толерантність, уміння викликати бажані результати в інших (переконання, розв'язання конфліктів, створення соціальних зв'язків).

Самоосвітня - здатність до навчання впродовж життя, окреслення планів, самоосвітня діяльність, самоаналіз та самоконтроль із застосовуванням сучасних форм, методів, технологій, навчально-інформаційних ресурсів.

Критичного мислення - уміння аналізувати, систематизувати, структурувати інформацію, виявляти в ній елементи достовірності, новизни в умовах швидких змін і різноманіття інформації.

Креативна - широкий кругозір, здатність ризикувати, кмітливість, нестандартне виконання завдань, створення неповторного продукту.

Інформаційно-цифрова - використання, моніторинг та контроль інформаційно-комунікаційних технологій.

Медіакомпетентність - знання, вміння, здібності щодо відбору, використання, критичного аналізу, оцінки, створення й передавання медіатекстів у різних видах, формах і жанрах, аналіз складних процесів функціонування медіа в соціумі.

Інклюзивна - знання, вміння, здатності виконувати професійні функції, зважаючи на особливі потреби клієнтів iз вадами здоров'я, їхня інтеграція у середовище готельноресторанного закладу, включення в активне суспільне життя, зниження ступеня соціальної ізоляції.

Рефлексивна - здатність до самоаналізу, усвідомлення власного душевного стану 3 метою вироблення стратегії подальшого розвитку й саморозвитку, визначення пріоритетів, ефективності й результативності навчальної та майбутньої фахової діяльності

Таким чином, зауважимо, що оновлення змісту професійної освіти й підготовки майбутніх фахівців готельно-ресторанної справи, комплексу компетентностей
Спеціальні (професійні) компетентності («тверді» навички - hard skills)

Експериментально-просктна - проєктування технологічних процесів виробництва продукції і послуг, здійснення сервісного процесу реалізації основних і додаткових послуг у закладах готельно-ресторанного та рекреаційного господарства.

Інноваційна - аналітичне мислення, оригінальність та ініціативність, здатність продукувати нові ідеї, відмова від традиційних схем мислення; розроблення нових послуг (продукції) та послуговування інноваційними технологіями виробництва й обслуговування споживачів.

Екологічна - усвідомлення, розуміння, критичне осмислення явищ, інформації і досвіду, пошук та обгрунтування варіантів вирішення екологічних проблем, теоретична й практична готовність ефективно здійснювати екологічно значущі професійні функції.

Інструментально-аналітична - пошук інформації та результативна робота 3 нею (використовуючи аналіз, синтез, узагальнення й систематизацію, засоби обліковофінансового та кількісного аналізу); отримання загальних результативних показників та здійснення оціночних висновків; використання комп'ютерної техніки та цифрових технологій як інструментарію для аналітичних досліджень не лише у фаховій діяльності, а й у повсякденному житті 3 метою прийняття управлінських рішень.

Дискурсивна - здатність до продукування цілісних, зв'язних і логічних висловлювань (дискурсів) у професійному мовленні; вибір лінгвістичних засобів рідної й іноземних мов залежно від типу висловлювання, ситуації спілкування, комунікативних завдань у сфері обслуговування.

Tехнічна - упорядкування суб'єктом готельно-ресторанного бізнесу технічної, економічної, технологічної та іншої документації, здійснення розрахункових операцій.

Технологічна - здійснення підбору технологічного устаткування та обладнання, вирішення питань, пов'язаних 3 раціональним використанням просторових та матеріальних ресурсів.

Соціально-економічна - знання, вміння, досвід діяльності, можливість мобілізації знань із метою прийняття раціональних та соціально відповідальних управлінських рішень у конкретних ситуаціях професійної діяльності.

Підприємницька - здатність до творчого пошуку та реалізації нових економічних ідей із метою вирішення різноманітних проблем у повсякденному житті та професійій діяльності; спрямованість діяльності майбутнього фахівця на досягнення успіху в готельно-ресторанному бізнесі й подальшій професійної діяльності у сфері обслуговування.

Лідерсько-управлінська - управління організацією, прийняття рішень у процесі провадження господарської діяльності суб'єктів готельно- ресторанного бізнесу.

Моніторингово-діагностична - виявлення, визначення й оцінка ознак, властивостей і показників якості продукції та послуг із метою забезпечення рівня виконання вимог споживачів.

Прогностично-моделююча - ініціювання створення концепції розвитку бізнесу, формулювання бізнес-ідеї розвитку суб'єктів готельно-ресторанного бізнесу, здійснення ними планування, управління і контролю професійної діяльності.

Cmaлості - здатність до неперервного навчання для забезпечення відповідного й відповідального ставлення до навколишнього природного середовища, формування загальної екологічної культури, нової системи морально-етичних цінностей 3 метою осучаснення менталітету особистості та моральності - суспільства сталого розвитку

в умовах глобалізаційних змін і реформування освітньої галузі в Україні, забезпечення їі якості можливе лише завдяки формуванню в здобувачів освіти інте- 
гральної, загальних і спеціальних (фахових, предметних) компетентностей.

Висновки. Отже, багатоаспектні дослідження науковців щодо проблем підготовки майбутніх фахівців сфери обслуговування, зокрема й готельно-ресторанної справи, в закладах вищої освіти, здійснений структурно-системний аналіз та власні наукові пошуки щодо процесу формування компетентності майбутніх фахівців готельно-ресторанної справи уможливили визначення комплексу компетентностей із метою успішної соціалізації, провадження професійної та/або подальшої навчальної діяльності, систематичного й цілеспрямованого індивідуального підвищення фахової компетентності, розбудови кар'єри та формування власної концепції життєвого успіху.

Перспективи подальших досліджень в означеному напрямі вбачаємо в аналізі технологій професійної підготовки в закладах вищої освіти та залученні до освітнього процесу представників професійних громадських інституцій.

\section{СПИСОК ВИКОРИСТАНОЇ ЛІТЕРАТУРИ}

Іванова, О. А. (2018). Особливості структурної складової частини професійної позиції фахівця сфери послуг. Науковий часопис НПУ імені М. П. Драгоманова. Серія 5. Педагогічні науки: реалії та перспективи. Київ: НПУ імені М. П. Драгоманова. № 61. С. 92-94.

Шевчук, С. С. (2018). Професійна підготовка фахівців сфери обслуговування на засадах компетентнісного підходу. Імідж сучасного педагога. Полтава: ПОІППО. № 5 (182). С. 41-45.

Радкевич, В. О., Кравець, С. Г., Козак, А. Р. (2020). Ключові компетентності (м'які навички) майбутніх фахівців індустрії гостинності. Colloquium-journal: електронне наукове видання. № 15 (67). URL: https:// cyberleninka.ru/article/n/klyuchovi-kompetentnosti-myaki-navichki-maybutnih-fahivtsiv-industriyi-gostinnosti (дата звернення: 10.03.2021).

Шестель, О., Куракін, О., Бишовець, Л. (2020). Специфіка формування soft skills фахівців сфери обслуговування в процесі професійної підготовки. Актуальні питання гуманітарних наук. Дрогобич: Дрогобицький державний педагогічний університет імені Івана Франка. Вип. 30. Т. 4. С. 280-283.

Зінченко, В. А. (2017). Особливості підготовки кадрів туризму і готельної справи в умовах євроінтеграції України та підвищення конкурентності туристичної галузі. Вісник Чернівецького торговельно-економічного інституту. Економічні науки. Чернівці: Чернівецький торговельно-економічний інститут. Вип. 3. С. 241-259.

Камишнікова, Г. В. (2017). Формування правової компетентності майбутніх фахівців готельного господарства та туризму в процесі професійної підготовки: дис. ... канд. пед. наук. Харків: Українська інженерно-педагогічна академія. 256 с.

Мединська, С. I. (2020). Розвиток та оцінювання soft skills при формуванні іншомовної компетентності у здобувачів вищої освіти в галузі туризму, готельно-ресторанної справи та міжнародного бізнесу. Вісник університету імені Альфреда Нобеля. Серія «Педагогічні науки». Дніпро: Університет імені Альфреда Нобеля. № 1 (19). С. 219-223.
Безкоровайна, Л. В. (2018). Теоретичні і методичні засади професійної підготовки майбутніх фахівців 3 туризмознавства у вищих навчальних закладах: дис. ... д-ра. пед. наук / Запорізький національний університет. Запоріжжя. 698 с.

Земліна, Ю. В. (2013). Структура та компоненти професійної готовності фахівців з туризму. Наукові записки Вінницького державного педагогічного університету імені Михайла Кочююинського. Серія «Педагогіка і психологія». Вінниця: ВНПУ імені Михайла Коцюбинського. № 40. С. 207-211.

Бурак, В. Г. (2020). Досвід професійної підготовки фахівців готельно-ресторанного господарства в закладах вищої освіти. Інноваиійна педагогіка. Одеса: Причорноморський науково-дослідний інститут економіки та інновацій. № 29. Т. 1. С. 88-92.

Гончар, Л. О. (2020). Обгрунтування концептуальної моделі підготовки фахівців готельно-ресторанної справи в Україні: організаційно-аналітичний аспект. Вчені записки ТНУ імені В. І. Вернадського. Серія «Економіка і управління». Київ: ТНУ імені В. І. Вернадського. Т. 31 (70). № 6. С. 39-49.

Дмитренко, Г., Каролоп, О. (2020). Компетентнісний підхід та його значення у формуванні професійної компетентності майбутніх бакалаврів готельно-ресторанної справи. Молодь і ринок. Дрогобич: Дрогобицький державний педагогічний університет імені Івана Франка. № 6-7 (185-186). С. 11-15.

Полуда, В. В. (2010). Формування професійної компетентності майбутніх фахівців із готельного господарства у процесі фахової підготовки: дис. ... канд. пед. наук / Інститут професійно-технічної освіти НАПН України. Київ. 364 с

Приймук, О. О. (2016). Особливості формування професійно важливих якостей майбутніх фахівців ресторанного бізнесу. Проблеми сучасної психології. Кам'янець-Подільський: Кам'янець-Подільський національний університет імені Івана Огієнка, Інститут психології імені Г. С. Костюка НАПН України. Вип. 33. С. 436- 448.

Нова українська школа. Концептуальні засади реформування середньої школи. (2016) / М-во освіти i науки України. URL: https://mon.gov.ua/ua/tag/novaukrainska-shkola (дата звернення: 10.02.2021).

Зубар, Н. М., Волкова, А. А. (2015). Проблеми формування професійної компетентності фахівців готельно-ресторанної справи: погляд роботодавця та випускника. Науковий часопис НПУ імені М. П. Драгоманова. Серія 5 «Педагогічні науки: реалї та перспективи». Київ: НПУ імені М. П. Драгоманова. № 51. С. 116-121.

Burak, V. (2020). Training of future specialists in hotel and restaurant industry in higher educational establishments in the conditions of distance learning. ScienceRise: Pedagogical Education. Kharkiv: Derzhavnyi vyshchyi navchalnyi zaklad «Universytet menedzhmentu osvity». № 6 (39). Pp. 16-20.

\section{REFERENCES}

Ivanova, O. A. (2018). Osoblyvosti strukturnoi skladovoi chastyny profesiinoi pozytsii fakhivtsia sfery posluh [Features of the structural component of the professional position of a service specialist]. Naukovyi chasopys NPU imeni M. P. Drahomanova. Seriia 5. Pedahohichni 
nauky: realii ta perspektyvy. Kyiv: NPU imeni M. P. Drahomanova. № 61. S. 92-94. [in Ukrainian].

Shevchuk, S. S. (2018). Profesiina pidhotovka fakhivtsiv sfery obsluhovuvannia na zasadakh kompetentnisnoho pidkhodu [Professional training of service specialists on the basis of the competence approach]. Imidzh suchasnoho pedahoha. Poltava: POIPPO. № 5 (182). S. 41-45. [in Ukrainian].

Radkevych, V. O., Kravets, S. H., Kozak, A. R. (2020). Kliuchovi kompetentnosti (miaki navychky) maibutnikh fakhivtsiv industrii hostynnosti [Key competencies (soft skills) of future professionals in hospitality industry]. Colloquium-journal: elektronne naukove vydannia. № 15 (67). URL: https://cyberleninka.ru/article/n/klyuchovi-kompetentnosti-m-yaki-navichki-maybutnih-fahivtsiv-industriyi-gostinnosti. [in Ukrainian].

Shestel, O., Kurakin, O., Byshovets, L. (2020). Spetsyfika formuvannia soft skills fakhivtsiv sfery obsluhovuvannia $\mathrm{v}$ protsesi profesiinoi pidhotovky [Specifics of forming soft skills of service specialists in the process of professional training]. Aktualni pytannia humanitarnykh nauk. Drohobych: Drohobytskyi derzhavnyi pedahohichnyi universytet imeni Ivana Franka. Vyp. 30. T. 4. S. 280-283. [in Ukrainian].

Zinchenko, V. A. (2017). Osoblyvosti pidhotovky kadriv turyzmu i hotelnoi spravy v umovakh yevrointehratsii Ukrainy ta pidvyshchennia konkurentnosti turystychnoi haluzi [Features of training specialists for tourism and hotel business in the conditions of European integration of Ukraine and increase of tourist branch competitiveness]. Problemy osvity. Chernivtsi: Chernivetskyi torhovelno-ekonomichnyi instytut. Vyp. 3. S. 241-259. [in Ukrainian]

Kamyshnikova, H. V. (2017). Formuvannia pravovoi kompetentnosti maibutnikh fakhivtsiv hotelnoho hospodarstva ta turyzmu v protsesi profesiinoi pidhotovky [Formation of legal competence of future specialists in hotel management and tourism in the process of professional training]: dys. ... kand. ped. nauk. Ukrainska inzhenerno-pedahohichna akademiia. Kharkiv. 256 s. [in Ukrainian].

Medynska, S. I. (2020). Rozvytok ta otsiniuvannia soft skills pry formuvanni inshomovnoi kompetentnosti u zdobuvachiv vyshchoi osvity v haluzi turyzmu, hotelno-restorannoi spravy ta mizhnarodnoho biznesu [Development and assessment of soft skills in the formation of foreign language competence in higher education in the field of tourism, hotel and restaurant business and international business]. Visnyk universytetu imeni Alfreda Nobelia. Pedahohichni nauky. Dnipro: Universytet imeni Alfreda Nobelia. № 1 (19). S. 219-223. [in Ukrainian].

Bezkorovaina, L. V. (2018). Teoretychni i metodychni zasady profesiinoi pidhotovky maibutnikh fakhivtsiv $\mathrm{z}$ turyzmoznavstva u vyshchykh navchalnykh zakladakh [Theoretical and methodical bases of professional training of future specialists in tourism in higher educational institutions]: dys. ... d-ra. ped. nauk / Zaporizkyi natsionalnyi universytet. Zaporizhzhia. 698 s. [in Ukrainian].

Zemlina, Yu. V. (2013). Struktura ta komponenty profesiinoi hotovnosti fakhivtsiv z turyzmu [Structure and components of professional readiness of tourism specialists]. Naukovi zapysky Vinnytskoho derzhavnoho pedahohichnoho universytetu imeni Mykhaila Kotsiubynskoho: pedahohika i psykholohiia. Vinnytsia: VNPU imeni Mykhaila Kotsiubynskoho. № 40. S. 207-211. [in Ukrainian].
Burak, V. H. (2020). Dosvid profesiinoi pidhotovky fakhivtsiv hotelno-restorannoho hospodarstva $v$ zakladakh vyshchoi osvity [Experience of professional training of specialists in hotel and restaurant economy in higher education institutions]. Innovatsiina pedahohika. Odesa: Prychornomorskyi naukovo-doslidnyi instytut ekonomiky ta innovatsii. № 29. T. 1. S. 88-92. [in Ukrainian].

Honchar, L. O. (2020). Obgruntuvannia kontseptualnoi modeli pidhotovky fakhivtsiv hotelno-restorannoi spravy v Ukraini: orhanizatsiino-analitychnyi aspect [Substantiation of the conceptual model of training of hotel and restaurant specialists in Ukraine: organizational and analytical aspect]. Vcheni zapysky TNU imeni V. I. Vernadskoho. Seriia: Ekonomika i upravlinnia. Kyiv. T. 31 (70). № 6. S. 39-49. [in Ukrainian].

Dmytrenko, H., Karolop, O. (2020). Kompetentnisnyi pidkhid ta yoho znachennia $\mathrm{v}$ formuvanni profesiinoi kompetentnosti maibutnikh bakalavriv hotelno-restorannoi spravy [Competence approach and its importance in the formation of professional competence of future bachelors in hotel and restaurant business]. Molod i rynok. Drohobych: Drohobytskyi derzhavnyi pedahohichnyi universytet imeni Ivana Franka. № 6-7 (185-186). S. 11-15. [in Ukrainian].

Poluda, V. V. (2010). Formuvannia profesiinoi kompetentnosti maibutnikh fakhivtsiv $\mathrm{z}$ hotelnoho hospodarstva u protsesi fakhovoi pidhotovky [Formation of professional competence of future specialists in hotel management in the process of professional training] : dys. ... kand. ped. nauk / Instytut profesiino-tekhnichnoi osvity NAPN Ukrainy. Kyiv, 364. [in Ukrainian].

Pryimuk, O. O. (2016). Osoblyvosti formuvannia profesiino vazhlyvykh yakostei maibutnikh fakhivtsiv restorannoho biznesu [Features of formation of professionally important qualities of future specialists of restaurant business]. Problemy suchasnoi psykholohi. Kamianets-Podilskyi: Kamianets-Podilskyi natsionalnyi universytet imeni Ivana Ohiienka, Instytut psykholohii imeni H. S. Kostiuka NAPN Ukrainy. Vyp. 33. S. 436-448. [in Ukrainian].

Nova ukrainska shkola. Kontseptualni zasady reformuvannia serednoi shkoly [New Ukrainian school. Conceptual principles of secondary school reform]. (2016) / M-vo osvity i nauky Ukrainy. URL: https://mon.gov.ua/ua/ tag/nova-ukrainska-shkola (data zvernennia: 10.02.2021). [in Ukrainian].

Zubar, N. M., Volkova, A. A. (2015). Problemy formuvannia profesiinoi kompetentnosti fakhivtsiv hotelno-restorannoi spravy: pohliad robotodavtsia ta vypusknyka [Problems of formation professional competence of specialists in hotel and restaurant business: the view of the employer and the graduate]. Naukovyi chasopys NPU imeni M. P. Drahomanova. Seriia 5. Pedahohichni nauky: realii ta perspektyvy. Kyiv: NPU imeni M. P. Drahomanova. № 51. S. 116-121. [in Ukrainian].

Burak, V. (2020). Training of future specialists in hotel and restaurant industry in higher educational establishments in the conditions of distance learning. ScienceRise: Pedagogical Education. Kharkiv: Derzhavnyi vyshchyi navchalnyi zaklad «Universytet menedzhmentu osvity». № 6 (39). Pp. 16-20. [in English].

Дата надходження до редакиії: 30.04.2021 p. 